\title{
Primož Trubar in Bartolomé de Las Casas
}

\author{
BARBARA PREgELJ \\ Univerza v Novi Gorici, Fakulteta za humanistiko, Vipavska 13, \\ Rožna Dolina, SI - 5000 Nova Gorica, barbara.pregelj@guest.arnes.si
}

SCN I/1 [2008], 52-62

\begin{abstract}
Primož Trubar in Bartolomé de Las Casas sta bila sodobnika. Najti je mogoče številne vzporednice $\mathrm{v}$ življenju obeh avtorjev (oba sta veliko potovala, s svojim delovanjem sta povzročala konflikte; opus obeh je obsežen, žanr polliterarni, stil pa precej podoben). Toda oba se tudi močno razlikujeta. V glavnem se razlikujeta glede pripadnosti različnima religioznima gibanjema 16. stoletja in njunega različnega pogleda $v$ razumevanju podobe.
\end{abstract}

Primož Trubar and Bartolomé de Las Casas were contemporaries. It is possible to draw several parallels regarding the life and work of both authors (they both travelled extensively, they caused conflicts due to their activities, their opus is extensive, their genre being semi-literary, and their style is quite similar). But they also differ in many respects. These differences are mainly due to the sense of belonging to two great religious movements of the $16^{\text {th }}$ century and their different attitude regarding the meaning of images.

Ključne besede: Primož Trubar, Bartolomé de Las Casas, primerjalna študija, literarne značilnosti reformacije, literarne značilnosti protireformacije

Key words: Primož Trubar, Bartolomé de Las Casas, comparative studies, characteristics of literature of Reformed Protestant Church, characteristics of literature of postTridentine Roman Catholic Church

Primerjava med Primožem Trubarjem (1508-1586) in Bartoloméjem de Las Casasom (1484-1566) temelji na osebni izkušnji: ko sem pred dobrimi petnajstimi leti prevajala de Las Casasovo Zelo kratko poročilo o uničenju Indij, ki je bilo napisano leta 1542 , dopolnjeno in natisnjeno pa natanko deset let pozneje, leta 1552, sem segla po Trubarjevih besedilih, s pomočjo katerih sem razreševala svoje prevajalske dvome, predvsem vprašanje, koliko naj prevod zrcali in/ali simulira jezik ter stil izvirnika. Za tole razmišljanje je povsem irrelevantno, 
kako sem se tedaj odločila, sta pa zame zaradi omenjenega oba pisca za vedno ostala povezana.

Ta povezava bi prav lahko ostala na nivoju bolj ali manj logične prevajalske asociacije, če ne bi bilo že na prvo žogo precej očitno, da je med življenjem in delom obeh mogoče potegniti precej vzporednic, glede na prostor, v katerem sta živela, pa opaziti tudi precej razlik. V svojem prispevku se bom zato osredotočila na primerjavo med njima, pri čimer bom morala predstavitvi Bartoloméja de Las Casasa posvetiti relativno več pozornosti, ker v slovenskem prostoru ostaja manj znan.

Primož Trubar in Barolomé de Las Casas sta bila sodobnika. Oba sta v času, ki sta ga dejavno sooblikovala, pustila globoke sledi. Vloga Primoža Trubarja v slovenski literaturi je neprimerljiva z mestom, ki ga Bartoloméju de Las Casasu namenjata španska in hispanoameriška literarna zgodovina: leta 1484 rojeni Seviljec je leta 1502 prvič potoval v Indije in s tem postal eden plodnejših avtorjev španskoameriških kolonialnih kronik, ustanovitvenih besedil hispanoameriške književnosti. De Las Casasove kronike po mnenju literarnih zgodovinarjev ne kotirajo tako visoko kot (ena sama, resda zelo zajetna) kronika Bernala Díaza de Castille, v kateri je pod naslovom Resnična pripoved o zavojevanju Nove Španije (Historia verdadera de la conquista de la Nueva España) toliko osupljivega zlivanja faktov in fikcije, da sta ga tako španskoameriška literarna kritika kot sodobni hispanoameriški roman oklicala za svojega predhodnika. Od literarne vede se lahko odmaknemo v antropologijo: de Las Casas ne velja, tako kot Bernardino de Sahagún, za enega redkih (verodostojnih) virov za proučevanje majevske civilizacije, ${ }^{1}$ pri njem tudi ni mogoče najti pričevanj o sinkretičnem zlivanju različnih elementov, procesu, ki je najbolj odločilno sooblikoval španskoameriško kulturo in jih najdemo denimo pri Peruancu Inku Garcilasu de la Vegi, ki je umrl istega dne kot Cervantes in Shakespeare ter si tako tudi z vsakoletnim praznovanjem dneva knjige zagotovil svoj košček večnosti. Kljub temu je ime Bartoloméja de Las Casasa prepoznavnejše od navedenih španskoameriških avtorjev ravno zahvaljujoč kratki knjigi, o kateri je bilo govora $\mathrm{v}$ uvodu in $\mathrm{s}$ katero si je prizadeval za prenehanje izkoriščanja Indijancev, pri tem pa tako očrnil ravnanje Španije v novem svetu, da so to $\mathrm{s}$ pridom izkoristile nekatere države (marsikatera tedaj še vzhajajoča kolonialna sila (za širjenje t. i. črne legende o Španiji. Uspeh te knjige, ki je že kmalu po avtorjevi smrti izšla v nizozemskem (1578), angleškem (1583), francoskem (1579) nemškem (1597) in latinskem (1598) prevodu, kasneje pa med drugim tudi v Italiji, na Portugalskem in na Japonskem, na ponovno objavo v Španiji pa čakala dolgo stoletje, ${ }^{2}$ je bil tako hkrati njen blagoslov in prekletstvo.

${ }^{1}$ De Sahagún, Bernardino. (1999). Historia General de las cosas de la Nueva España. Porrúa: México, D. F.

2 1552, Sevilla. Poznejše izdaje (do 1980): 1646, Barcelona; 1812, London; 1813, Bogota; 1820, Cádiz; 1821, Philadelphia; 1821, Puebla (Mehika); 1822, Ciudad de México; 1822, Pariz; 1879, Madrid; 1924, Buenos Aires; 1945, Ciudad de México; 1945, Pariz; 1957, Ciudad de México; 1958, Madrid; 1966, Buenos Aires, 1977, Madrid; 1979, Barcelona. 
Kljub drugačnemu vrednotenju njunega dela je mogoče med obema piscema potegniti precej vzporednic. Delo obeh mož je kolumbovsko. Trubarjevo pionirstvo je večplastno: jezikovno, literarno, prevajalsko, tiskarsko, knjigotrško, teološko, dogmatično, cerkvenopravno, glasbeno, šolsko; de Las Casasovo bolj v dobesednem smislu: ko je spremljal Kolumba na njegovem drugem potovanju v Novi svet, je bil še zavojevalec, lastnik encomiende, kasneje je postal duhovnik (potem pa 1522 stopil še $\mathrm{v}$ red dominikancev) in zlagoma vse bolj goreč zagovornik mirnega pokristjanjevanja Indijancev. Trubar je bil vse prej kot prerok v svoji domovini, čeprav je dediščina, ki ji jo je zapustil, neprecenljiva; bil je odpadnik, a dovolj pragmatičen, da se ni spuščal v teološke dispute; videti je, da je de Las Casas v teh prav užival, pri čimer sta se med njegovimi številnimi poslušalci znašla tudi dva španska kralja (Fernando Katoliški, Karel V.). Tudi zaradi de Las Casasovih prizadevanj v širšem kontekstu razprav o zavojevanju je Karel V. leta 1542 sprejel t. i. »nove zakone«, s katerimi je bilo delno odpravljeno suženjstvo in izkoriščanje Indijancev ter dedovanje encomiend. Tako Trubar kot de Las Casas sta živela za uresničenje svoje ideje: da bi jo lahko udejanila, sta očitno morala žrtvovati marsikaj, videti pa je tudi, da sta vztrajno vadila soočanje z odkritimi napadi, preganjanji in kritikami ter rovarjenji in klevetami; de Las Casas je bil pri tem uspešnejši, saj ni bil nikoli pregnan, čeprav so izpričani njegovi spori s številnimi visokimi cerkvenimi dostojanstveniki (Juanom Rodríguezom de Fonseco, Juanom de Quevedom, najbolj goreč pa s Juanom Ginésom de Sepúlvedo).

Trubar in de Las Casas sta veliko potovala. Podatka o kilometrih, ki jih je na poti prebil Trubar, nisem našla, a če seštejem najpomembnejše kraje na njegovi življenjski poti, je kilometrov več kot 10.000. Poznavalci de Las Casasovega življenja in dela so natančnejši: izračunali so, da je dominikanec napravil 22.442 španskih milj (leguas), od tega je desetkrat prečkal Atlantik in tako v prepotovanih kilometrih prekosil ne le Trubarja, temveč tudi veliko večino Evropejcev 15. in 16. stoletja (z izjemo Kolumba, Magellana, Draka in Nelsona), med velikimi osvajalci in popotniki pa celo Aleksandra Velikega, Julija Cezarja in Marka Pola (Borges 1990: 15).

Zaradi tolikšne potovalne vneme je skorajda presenetljivo, da je opus obeh tako obsežen. Trubarjevi bibliografi so našteli 26 knjig oz. 31 tiskov (če upoštevamo posamezne dele, ki so bili posebej vezani in prodajani), 10 posvetil za hrvaške knjige (v nemščini) in 86 rokopisov (večinoma pisma); poleg že omenjenega Zelo kratkega poročila je Las Casas napisal, kot sam pravi, »veliko število listov, v latinščini in španščini jih je več kot dva tisoč« (BAE, CX, 470b), skupaj 369 naslovov, od tega je $13 \mathrm{knjig}$, ostalo so poročila in pisma.

Obema piscema je skupno, da je njuno pisanje (tukaj se pri Trubarju omejujem na prozo) večinoma polliterarno (oznako v zadnjem času uporablja Kmecl 2004, ki ga povzema po Pogačnikovi rabi) - termin nabožna književnost (Grdina 1997) puščam ob strani, saj ga španskoameriška literarna veda ne pozna in ne uporablja - in izrazito (konfesionalno) polemično (Pogačnik 1998), kar narekuje tudi organizacijo diskurza. Kakšno, bo pokazalo vzporedno branje Zelo kratkega poročila in Katekizma z dvema izlagama iz 1575. Slednjega sem 
izbrala, ker velja za eno polemičnejših Trubarjevih knjig in vrhuncev njegovega ustvarjanja.

Poglavitni namen de Las Casasovega pisanja (in to ne le v Zelo kratkem poročilu) je razkriti in obtožiti ravnanje Špancev v Novem svetu ter predlagati ukrepe, ki bodo to spremenili; Trubarjev Katekizem z dvema izlagama vsebuje, kot napoveduje že naslov, katekizem, »Eno pridigo od starosti te prave inu krive vere, kerstčovane, mašovane, čestčena tih svetnikou, od cekovnih inu domačih božyh službi, iz Sv. Pisma, starih kronik inu vučenikov vkupe zbrana, Ta mahina agenda, otročie molitve«. ${ }^{3}$ Besedilo, ki so ga poznavalci (Rupel, Rajhman, Glavan) vsebinsko razdelili na štiri sklope, torej sledi osnovnim Trubarjevim prizadevanjem za posredovanje temeljnega nauka o veri, obenem pa ponuja tudi orodje, da bi le-to bralci in poslušalci lahko tudi sami spoznavali in dejavno živeli. Še zlasti zanimiv je drugi del besedila, v katerem je Trubar zelo oseben, saj govori o domačih razmerah. Z besedami Mirka Rupla: »Kjer se mu le ponudi prilika, da udari po nasprotnikih, postane zgovoren in oster, pokaže ogorčenje in pomilovanje hkrati in, kakor večkrat, prodre skozi teološko umovanje njegovo jarko čustvo. Agresivnost pa izvira v tej dobi tudi odtod, ker se je v njegovi domovini začela javljati protireformacija (Rupel 1966: 25) in še: »ta poglavja [drugega dela] so napisana bojevito in z notranjim ogorčenjem; zato mu beseda tako gladko teče« (Rupel 1962: 204).

Polemična ost obeh avtorjev je opazna že v Uvodu, kjer pojasnjujeta, zakaj sta svoji knjigi sploh natisnila. Trubar v svojem zavrača napade »zupernikov, ty[h] papežnikov« na »lutherske [od] te nove vere imenovane« in pojasnjuje, da je knjigo napisal ravno zato, da bi se obranil pred njihovim klevetanjem. Knjiga je Trubarju orožje, zato pravi: »Obtu kupite za male denarie le-te buqvice, čestu preberite« (Trubar 2002: 38): če je namreč knjiga poceni, ji je olajšan vstop v Gutenbergovo galaksijo, ta vstop pa je, tega se Trubar zaveda, po svoji daljnosežnosti enak odkritju Novega sveta, o čemer v uvodnem razmišljanju, v katerem spregovori tudi o razlogih za tiskanje svoje knjige, piše de Las Casas:

Vse, kar se je zgodilo v Indijah - od njih čudežnega odkritja, ki je povzročilo, da so se tja odpravili mnogi Španci, pa do današnjih dni -, se je vsem tistim, ki sami niso tega doživeli, zdelo tako neverjetno, presenetljivo in pomembno, da je zaradi svoje pomembnosti zameglilo, utišalo in potisnilo v pozabo vsa druga dejanja, naj so bila še tako velika, da bi v drugačnih časih o njih govoril ves svet (Las Casas 1993: 23)

A v raju, v katerem so Evropejci iskali izvor večnega življenja, našli pa obilje vseh vrst, je bilo tudi trpljenje, uničevanje, zločini. Bartolomé de Las Casas je o njih najprej govoril in »stvari, ki jih je pripovedoval, so v vseh pripovedovalcih vzbudile nemalo zanosa in začudenja, zato so ga naprosili in mu naložili, naj na kratko svoje prigode tudi zapiše. Storil je, kot mu je bilo naročeno« (prav tam). A ker to ni ustavilo pohlepa in častihlepja zavojevalcev, se je odločil in dal (skoraj skrivaj) svojo knjigo tudi natisniti (»da bi jo njegovo Visočanstvo bralo z

\footnotetext{
${ }^{3}$ Besedilo navajam po znastveno-kritični izdaji v Zbranih delih (ZD II, 37-410)
} 
večjo lahkoto«), saj je šele tako postala zares učinkovito orožje. Obema piscema je torej skupno, da sta uporabljala oba načina sporočanja, najprej ustnega, nato pisnega, pri čemer sta se zavedala, da le zapisano o(b)stane, in da je to, kar je zapisano, tudi bolj verjetno, tako za tiste, ki knjigo berejo, še bolj pa za tiste, ki sami ne znajo brati in zato besedilo lahko le poslušajo. Ni naključje, da je bilo ravno Sveto pismo tisto besedilo, za prevod katerega so si prizadevali protestantje in za rabo katerega v latinščini so si prizadevali protireformatorji. Sveto pismo je bilo namreč knjiga vseh knjig in zaradi njegovega pomena ga je t. i. magična, predrazsvetljenska mentaliteta enačila z vsemi drugimi knjigami, kar je pomenilo, da se je vsaka knjiga že samo zaradi dejstva, da je bila (tako kot Sveto pismo) knjiga, svojim poslušalcem in bralcem zdela resnična (Leonard 1979: 19).

Oba Uvoda postrežeta tudi s slikanjem opozicije, ki bo za obe besedili ključna: pri Trubarju gre za disput med »lutherskimi« in "papežniki«, med novo in staro vero, med temi, ki zares sledijo božji besedi in temi, ki se od nje odvračajo, pri de Las Casasu pa za opozicijo med poboji in uničenji nedolžnih ljudi (Indijancev) in zahrbtnimi zločinci (španskimi zavojevalci). To, kar je tokrat pri de Las Casasu le nakazano (je pa ena osrednjih antitetičnih prispodob njegove knjige -, je pri Trubarju že ubesedeno: govor je o ovcah in volkovih. Gre za parafrazo besed, s katerimi je Jezus nagovoril apostole, le da je pri Trubarju hudomušno obrnjena: volkovi se pritožujejo, da jim je ovca, ki je pila niže ob potoku, skalila vodo. Tako Trubar že v Uvodu tudi posredno, z rabo retoričnih sredstev pokaže na to, katera vera je po njegovem pravilnejša.

V nemškem Posvetilu Trubar vztraja pri primeri z ovcami in volkovi: tokrat jezuite imenuje »volčja bratovščina v ovčjem oblačilu« (SPP, 213), sebe pa pastirja, ki mora skrbeti za čredo tudi tako, da jo »brani in svari pred volkovi« (SPP, 214). Nevarnost, o kateri govori najznamenitejši slovenski protestant, so (danes izgubljene) tiskane knjige, v katerih jih klevetajo jezuiti in Paherneker, zato nanje odgovarja, pa čeprav »star, bolan in hrom « (SPP, 214), kar ponovno priča o tem, kako dobro se je zavedal moči in pomena tiskane besede. Še zlasti za mladino: ker jo posveča svojemu kumčetu Francu Juriju Reinskemu, Trubar sklepa, da jo bo mladina tem raje prebirala. Podobno kot Trubar v nemškem Posvetilu tudi Bartolomé de Las Casas v Uvodu pokaže, da obvlada slavilno retoriko. Njegovi cilji so očitno težje dosegljivi, zato si poišče mogočnejšega zaščitnika: princa Filipa, španskega prestolonaslednika, ki ga primerja s pastirjem, ki edini lahko odpravi zlo nad podložniki, za katerih duhovno blaginjo je odgovoren. De Las Casas je pri antitetičnemu slikanju tokrat določnejši: zavojevalci so tirani, njihova dejanja, ki so bila storjena miroljubnemu, ponižnemu in krotkemu indijanskemu ljudstvu, pa krivična, obsojanja vredna ter grajana in prekleta po božjih in človeških zakonih. Da ne bi bil sokriv pogubljenja tako enih kot drugih in da bi bil karseda učinkovit v svoji sporočilnosti, de Las Casas pogosto uporablja tudi superlative, aumentative in pretiravanja: »Vsak dan so večje predrzne in nerazumne želje tistih, ki brez vsakih pomislekov prelivajo neskončne količine človeške krvi, izseljujejo iz domov njihove prebivalce in lastnike, pobijajo tisoče milijonov ljudi in pustošijo njihovo zemljo ter ropajo njihove ogromne zaklade« (Las Casas 1993: 25). Presežki na obeh straneh, ki 
so raztreseni po vsej knjigi, utrjujejo črno-belo slikanje, obenem pa razkrivajo de Las Casasovo globoko naklonjenost do Indijancev in ljubezen do bližnjega, ki seže dlje kot le skrb dobrega pastirja: je njegovo najopaznejše vodilo. ${ }^{4}$ Primerjava s Trubarjem je kot na dlani: ne le, da je bil ta prvi, ki je svoj narod nagovoril s prav nič vzvišenim »Lubi Slovenci!« in mu želel »milost, mir in vse dobro od Boga očeta po Jezusu Kristusu«, temveč je tudi »često vzdihnil in vzkliknil k Bogu, naj se zaradi posvečenja svojega imena in razširitve svojega kraljestva milostno ozre tudi na naše ubogo, preprosto, dobrosrčno slovensko ljudstvo, naj mu prizanese in ga obdari z veliko milostjo in darom, da bi se tudi njegov jezik pisal in bral kakor jezik drugih narodov« (SPP, 72). Trubarju so se Slovenci smilili, ker so tako malo vedeli (prim. tudi znamenito pismo Bohoriču 1. avgusta 1565), a tudi, ker so nadnje prišli Turki. Za turške vpade pa so »krivi papežniki s svojo novo vero, malikovanjem, trinoštvom, preganjanjem in nesramnim življenjem« (SPP, 216). Ko se bodo ljudje vrnili k stari veri, je trdil Trubar, bodo te nadloge izginile. Tudi de Las Casas je sočustvoval s svojo domovino Kastiljo: s svojim delom jo je skušal rešiti, saj se je bal, da jo bo Bog uničil »zaradi velikih grehov zoper njegovo vero in čast, ki so jih njeni prebivalci zagrešili proti svojim bližnjim« (Las Casas 1993: 105).

Takšne trditve se danes morda zdijo pretirane, a pričajo o nekdaj povsem samoumevni absolutni veljavnosti božjega vatla tudi za vse zadeve tuzemskega sveta. Tako Trubar kot de Las Casas sta bila goreča božja pastirja in iz njunega pisanja je razvidno, da sta kot prava »ribiča duš« na svojih ramah nosila veliko težo, o čemer pričata tudi osrednja dela njunih besedil. De Las Casasovo besedilo je dokaj pregledno in precej enostavno grajeno: gre za naštevanje ozemelj v zaporedju, kot so jih Španci odkrivali in nato po piščevem pričevanju tudi uničili (Hispaniola, Sant Juan, Jamajka, Kuba, Tierra firme, Nikaragva, Gvatemala, Nova Španija, Panuco, Jalisco, Yucatán, Cartagena, Sancta Marta, Obala biserov, Parija, Trinidad, reka Yuyapara, Venezuela, Florida, Río de la plata, Peru, Nova Granada). Avtor večinoma povsod uporablja enak pripovedni postopek: ozemlje opisuje pred in po prihodu zavojevalcev, s čimer še poudari kontrastiranje med antagonisti. Za ilustracijo navajam enega izmed opisov kraljestev na otoku Hispaniola:

Prostor, na katerem se razprostira [kraljestvo Magua], je ena najizvrstnejših in občudovanja vrednih stvari na vsem svetu /.../ Čez trideset tisoč rek in potokov teče čezenj, izmed katerih jih je dvanajst vsaj tako velikih kot Ebro in Duero in Guadalquivir. Vse reke, približno dvajset do petindvajset jih je, ki pritečejo iz gorovja, ležečega na zahodu, so polne zlata. /.../ Kralj in gospodar tega kraljestva se je imenoval Guarionex. Njegovi vazali so bili tako mogočni veljaki, da je vsak izmed njih lahko zbral šestnajst tisoč vojščakov, ki so bili pripravljeni služiti Guarionexu, in sam sem spoznal nekatere izmed njih. Sam kralj Guarionex je bil zelo ubogljiv in kreposten, miroljuben po naravi in vdan kastiljskima kraljema. Na njegov ukaz so vsi njegovi ljudje, ki so imeli svojo hišo že nekaj let, morali dati toliko zlata, da so z

${ }^{4}$ Zato so ga pogosto imenovali tudi apostol Indijancev. Njegova duhovna zapuščina je v Chiapasu s stoletji postajala vse pomembnejša, kar dokazujejo tudi dogodki po letu 1994. 
njim napolnili notranjost kraguljčka. Ker Indijanci tega otoka niso bili vešči nabiranja zlata $\mathrm{v}$ rudnikih in torej niso mogli nabrati toliko zlata, kot jim je bilo ukazano, so za polovico zmanjšali mero, ki je tako znašala kraguljčkovo polovico, napolnjeno z zlatom. Ta poglavar se je ponudil v službo kralju Kastilje in hotel narediti kmetijo /.../ vse to je ponujal v zameno za to, da ga ne bi več prosili za zlato, ker je trdil, in to upravičeno, da ga njegovi vazali ne znajo nabirati. /.../ Za plačilo so temu kralju, dobremu in velikemu gospodu onečastili ženo - neki poveljnik in slab kristjan ji je storil silo. Indijanski poglavar bi lahko počakal, da preteče nekaj časa, in zbral svoje ljudi in se maščeval, a se je odločil in odšel, da bi se skril in umrl izgnan iz svojega kraljestva /.../ Ko so kristjani izvedeli za njegov beg in njegovo skrivališče, so začeli vojno s posestnikom, ki ga je skrival. Predno so ga našli, so pobili mnogo ljudi, njega pa ujeli in uklenili v verige in okove. Potem so ga posadili na neko ladjo in ga hoteli odpeljati v Kastiljo. Ta ladja se je izgubila nekje na morju, z njo vred se je potopilo tudi mnogo kristjanov in velika količina zlata, med drugim tudi zlato zrno, ki je bilo veliko kot hlebec kruha /.../ Tako je Bog kaznoval tiste, ki so storili tako veliko krivico (Las Casas 1993: 33-34).

Opis idilične, rajske pokrajine, v kateri živijo prijazni in miroljubni prebivalci, preide v pripoved o nasilju nad njimi, ki je dramatično stopnjevana. V opisih pripovedovalec prehaja od dejstev $\mathrm{v}$ fantastično (zlato zrno, veliko kot hlebec kruha), trudi se za objektivnost, a se prepusti subjektivnosti in vrednotenju, pripoved pa sklene z močno poudarjenim moralnim naukom. Gre za eksempel, zgled, ki jih je srednjeveška literatura polna, gojili pa so ga tudi kasneje, predvsem v pridigah, ko so govorniki z njimi skušali pojasniti abstraktnejše teološke vsebine. Eksempli so zametki zgodbenosti; slovenska literarna zgodovina jih je našla tudi pri Trubarju, iz te rabe pa izpeljala slikovito primero o kriminalki kot naslednici pridige (Kmecl 1975).

Pomudimo se še pri nekaj daljših izsekih, v katerih de Las Casasa opisuje svoje antagoniste:

Vse te različne in številne ljudi vseh vrst in narodov [Indijancev] je Bog ustvaril kot najbolj preproste, brez zlobe in zvijačnosti, ubogljive in zelo zveste svojim gospodarjem in kristjanom, katerim radi služijo. So najbolj ponižni, potrpežljivi, miroljubni in mirni, kar jih je na svetu, niso prepirljivi, hrupni, se ne razburjajo ali jezijo, niso maščevalni in ne sovražni, še več, so brez vsakršne želje po maščevanju. Prav tako so izredno krhke, vitke in nežne postave, kot med nami niso niti sinovi princev in visoke gospôde, ki so bili vzgojeni v gosposkem in izbranem okolju. Čeprav so nižjega rodu, zelo težko opravljajo težka dela in prav hitro jih lahko pokoplje katerakoli bolezen.

Ti ljudje so zelo revni, nimajo niti nočejo imeti nikakršnih dobrin, zato tudi niso ne ošabni in ne pohlepni in ne častihlepni. Njihova prehrana je tako revna, da se še hrana svetih očetov puščavnikov zdi bolj obilna in slastna. /.../ Ti ljudje so zelo bistrega, svobodnega in živega duha, zelo krotki in dovzetni za vse dobre nauke in pripravljeni brez vseh zadržkov sprejeti našo sveto katoliško vero in njene krepostne navade: noben narod med vsemi, kar jih je bilo po volji božji ustvarjenih na tem svetu, nima pri tem manj težav. /.../ K tem krotkim ovcam, ki jih je Stvarnik obdaril s prej omenjenimi čednostmi, so prišli Španci, ki so bili kot volkovi, tigri in najbolj okrutni levi, ki že dneve niso dobili nič za pod zob. V štiridesetih letih, 
ki so minila od njihovega prihoda do dandanes, ne počno drugega, kot uničujejo njihovo imetje, jih pobijajo, zastrašujejo, žalijo, trpinčijo na različne nove načine, za katere nihče še ni slišal in jih ni videl in ne bral o njih. Nekatere izmed njih bomo kasneje opisali, ker jih je bilo toliko, da od vseh teh milijonov duš, ki smo jih videli, na otoku Hispaniola dandanes ne živi niti dvesto domorodcev. /.../

Tisti, ki so se podali v Novi svet in so se imenovali kristjani, so se posluževali dveh načinov, ko so hoteli odstranjevati in izbrisati iz zemeljskega površja tista uboga ljudstva. Prvi način so bile nepravične, krute, krvave in tiranske vojne. Drugi način /.../ pa je bil ta, da so jih podvrgli najhujšemu, groznemu in grobemu suženjstvu, v katerem ne morejo vzdržati niti zveri, kaj šele ljudje. /.../ Razlogi, zaradi katerih so kristjani ubili in pogubili tako veliko število duš, so bili naslednji: zlato in bogastvo, ki so si ga hoteli nagrabiti v čim krajšem času /.../, nenasitna lakomnost in častihlepnost, večja, kot je na svetu sploh mogoča, rodovitna in bogata ozemlja, kjer so naleteli na izredno ponižne in potrpežljive ljudi, ki si jih ni bilo težko podrediti. Vendar jim Španci niso namenili nobene pozornosti in obzirnosti (govorim po pravici o tem, kar vem in kar sem ves ta čas imel priliko videti). Spoštovali jih niso niti toliko kot divje zveri - daj Bog, da bi jih spoštovali in z njimi ravnali kot z zvermi. Z njimi so ravnali tako in še slabše kot z gnojem na cesti. Tako so skrbeli za njihovo življenje in dušo, da so zategadelj številni ljudje, milijoni, umrli brez vere in zakramentov. Takšna je občeznana in sramu vredna resnica, ki jo vsi, čeprav tirani in morilci, poznajo in izpovedujejo: Indijanci iz vseh Indij niso kristjanom nikoli storili nič slabega. Nasprotno, imeli so jih za prišleke z neba, dokler niso bili oni sami in njihovi sosedje deležni njihovih zlih dejanj: ropanja, umorov, posilstev in ponižanja (prav tam: 27-31).

Jasno je, da zaradi obtožujoče, angažirane narave svojega pisanja Bartolomé de Las Casas vseskozi pretirava tako v poudarjanju negativnega ravnanja kristjanov (ki pa jih ne navaja poimensko), iz katerega so izvzeti nekateri redovniki -, kot v idealizaciji poganskih Indijancev. Črno-belo kontrastiranje ima tako tudi mnemotehnično vlogo, tako kot njegov osrednji pripovedni postopek, hiperbola, povečevanje, ki pa je obenem tudi zeitgeistovski, saj je sad dobe, ki je odkrila Novi svet, a ga ni bila sposobna razumeti. Podobno vlogo ima tudi naštevanje, ki ga vseskozi nadgrajuje z lastnim vrednotenjem, predvsem obsojanjem; precej uporablja metonimijo, pogoste so tudi ironije. Uporablja močne izraze (uničenje, tiran), na trenutke je tudi patetičen in dramatičen, posebno učinkoviti za pritegovanje pozornosti so eksempli. A Bartolomé de Las Casas je tudi prvi, ki pozitivno ovrednoti in v takšni luči popiše 'dobrega divjaka' (termin je seveda poznejši). Ravno ti opisi, je razmišljal de Las Casasov sodobnik, zgodovinar in biograf Sv. Janeza od Križa, Jerónimo de San José, »so ljubki in plemeniti, saj bolj zadovoljujejo okus kot resnično potrebo, kajti opisi so kot slike in risbe krajev, kjer se je zgodilo to, o čimer se pripoveduje, in dajejo nekaj barve očem za informacijo« (San José 1957: 299).

Ravno v tem se po mojem razkrije najpomembnejša razlika med obema piscema. V osrednjem delu besedila (tj. v njegovem drugem delu) tudi Trubarjev jezik postaja barvitejši, čeprav tudi on večinoma ostaja znotraj črno-belega slikanja obeh polov opozicije med protestanti in 'papežniki': 
O, vi molčeči psy, vi hudi, bozi, revni, prekleti, hudičevi fary inu menihi, kir vi taku zavolo vašiga smerdečiga trebuha timu zludiu, nega tovarišem inu služabnikom, te boge presproste ludi inu te vaše ovčice pustite zapelati temu zludiu, s to pravo bessedo božyo inu s tem katekizmom ne stoyte zuper inu ne vučite, da bi se ta celi katekizmus prou navučili, po nim verovali, molili, Bogu služili, de bi v nebessa ine nekar timu zludiu na deil prišli. Vi ste taki naieti pastyri inu vulkuvi, de h timu vsimu molčite (Trubar 2002: 182).

Nadaljuje se uvodna primera med ovco in volkom, a besedišče postaja neposrednejše, surovejše, celo žaljivo, kar očitno razkriva piščevo močno osebno vpletenost. Učinkovitost dosega tudi s stopnjevanjem in kopičenjem pojmov, a tudi z rabo eksemplov (med številnimi Trubarjevimi eksempli je ravno iz Katekizma z dvema izlagama nekaj najbolj znanih, kot so: o cerkvi na Rašici, ki jo je dal njegov oče poslikati; o Marijinem onečaščenju; o obrekovanju, da krščuje otroke v Ljubljanici; o menihih v Padovi, ki so naredili, da je jokal Marijin kip; o ženski v iški fari, ki je čakala, da ji bo Marija obudila mrtvega otroka; o prekrščevalcu Hubmeierju, itd.), naštevanjem, pretiravanjem, kopičenjem ipd. Podobno kot pri de Las Casasu imajo uporabljena retorična sredstva tudi pri Trubarju predvsem mnemotehnično vlogo. Tako pisec svoj namen, razložiti in prepričati, dosega tako neposredno kot posredno. A če si med eksempli ogledamo verjetno najznamenitejšega, ki govori o očetovi poslikavi cerkve na Rašici, opazimo, da v njem manjkajo prav opisi, ki de Las Casasovi pripovedi dajejo barvitost. Še več: Trubar uporabi eksempel ravno zato, da bi ljudi odvrnil od čaščenja podobe, kot lahko beremo:

Mui oča, kadar ie na Rašici sv. Ierneia cehmošter bil, ie bil pustil to cerkou vso enimu krovaškimu malariu malati. Ta ie tim svetnikom, suseb tim jogrom, velike brade inu mostače po tursku inu krovašku namalal. Natu so v tim 1528. leitu ty Turki prišli, to cerkou požgali in sv. Ierneia pilda v kori, kir nei mogel zgoreti, roke odbili, oči iztenknili inu tu malane ie vse proč palu. Timu malariu ie bil mui oča dal dvaiseti vogerskih zlatih. Te iste bi bil bule nalužil, de bi bil ene štiri vole kupel inu tim bozim sosedom dal, de bi žnimi bili orali, suie otroke živili. In summa. De ty dobri, preprosti kerščeniki teim bule inu ležei zastopio, de tu klicane na svetnike, molene inu preveliku češčene, nim cerqve zydane, rumane inu praznovane nei prou, ie Bogu, nega bessedi inu zapuvidi zuper (prav tam: 226).

Trubarjev eksempel tako tudi posredno, na formalni ravni, $\mathrm{z}$ organizacijo diskurza, poudarja zavračanje podobe kot enega osnovnih postulatov protestantizma, ki ga obenem ubesedi, teološko utemelji, variira ter ponovi tudi bolj neposredno, tj. na ravni vsebine.

Protireformacija je v rabi podobe, kot je očitno tudi pri de Las Casasu, stala na povsem nasprotnem bregu, s čimer je sledila zapovedim 25. zasedanja Tridentinskega koncila (1563), kjer je bilo med drugim tudi rečeno:

Marljivo učite škofe, naj preko pripovedi o misterijih zveličanja, izraženih s slikami in drugimi podobami, poučujejo in utrjujejo ljudstvo v rečeh vere, ki se jih je treba stalno spominjati in o njih premišljevati. Vsaka sveta podoba je zelo koristna. $\mathrm{Ne}$ 
le, ker vernike spominja na koristi in darove, ki so jih prejeli od Jezusa Kristusa, temveč tudi, ker ljudje tako ugledajo čudeže, ki jih je Bog storil preko svetnikov in zgledov iz njihovega življenja. Zato se lahko zahvalijo Bogu, svoje življenje in navade priličijo življenju svetnikov ter tako vzljubijo Boga in živijo v krščanski ljubezni (Sebastián 1989: 62-63).

Sklepi Tridentinskega koncila so bili v Španiji uzakonjeni leta 1564, a dovzetnost za podobo je eden od temeljev ignacijanske pedagogike in po mnenju mnogih eden od razlogov njenega uspeha. Sveti Ignacij je v prvi izmed Duhovnih vaj namenil precej pozornosti »kontemplaciji ali meditaciji vidnih stvari [..., ko] z očmi domišljije gledamo konkreten kraj, kjer je predmet kontemplacije« (1991: 23), nekateri jezuitje pa so šli še dlje: podobo v duhu je zamenjala konkretna podoba:

Da bi laže meditirali, vzamemo podobo, ki predstavlja evangelijsko skrivnost in tako še preden začnemo z meditacijo, opazujemo podobo in si na njej ogledamo vse potrebno, da bi o tem bolje premišljevali med meditacijo /.../ podoba [je namreč] narejena premišljeno in povsem v skladu z Evangelijem (Borja 1912: 7).

Še učinkovitejša je bila metoda jezuita Jerónima Nadala, ki je 1593 v Antwerpnu izdal Podobe svetopisemske zgodovine (Evangelicae historiae imagines), v kateri je združil natisnjeno podobo in besedilo. Nadalova metoda je nova in uspešna: po eni strani posodobi ignacijansko vidno-intuitivno metodo osebne molitve, po drugi strani pa z novimi sredstvi, tiskom in jedkanicami sledi navodilom Tridentinskega koncila. Naj zato strnem z vrnitvijo v slovenske okvire: za slovensko literaturo je ustanovitveno dejanje slovenskih protestantov neprecenljivo, a za njen specifičen razvoj je pomenljiv tudi protireformacijski odnos do zapisane besede ter podobe, ki so mu od Čandka do Valvazorja vtisnili močan pečat jezuitje. Posttridentinske literarne pobude z zahoda bi zato kazalo premisliti predvsem v luči odnosa med podobo in znakom.

\section{LITERATURA}

Pedro BORGES, 1990: Quién era Bartolomé de Las Casas. Madrid: Ediciones Rialp. Francisco de BORJA, 1912: Meditaciones para todas las dominicas y ferias del año y para las principales festividades. Madrid.

Matjaž KMECL, 1975: Od pridige do kriminalke ali o meščanskih začetkih slovenske pripovedne proze. Ljubljana: Mladinska knjiga.

- -, 2004: Tisoč let slovenske literature. Drugačni pogledi na slovensko literarno in slovstveno preteklost. Ljubljana: Cankarjeva založba.

Bartolomé de LAS CASAS, 1989: Brevísima relación de la destrucción de las Indias. Madrid: Cátedra. 
- -, 1993: Zelo kratko poročilo o uničenju Indij. Las Casas, Bartolomé de: Uničevanje Indijancev in evangelizacija. Celje: Mohorjeva, 23-121.

Igor GRDINA, 1997: Starejša slovenska nabožna književnost. Ljubljana: DZS.

Irwing A. LEONARD, 1979: Los libros del conquistador. Mexico: FCE.

Ignacij LOJOLSKI, 1991: Duhovne vaje. Ljubljana: Župnijski urad Ljubljana-Dravlje. Jože POGAČNIK, 1998: Slovenska književnost 1. Ljubljana: DZS.

PREGELJ, Barbara, 1992: Reflexiones sobre Brevísima relación de la destrucción de Las Indias de fray Bartolomé de Las Casas. Verba hispanica, 2, 131-134.

Jože RAJHMAN, 1986: Pisma Primoža Trubarja. Ljubljana: SAZU.

Mirko RUPEL, 1962: Primož Trubar. Življenje in delo. Ljubljana: Mladinska knjiga. - -, 1966: Slovenski protestantski pisci. Ljubljana: DZS.

Jerónimo de SAN JOSÉ, 1957: Genio de la Historia. Vitoria: Ediciones »El Carmen«. Santiago SEBASTIÁN, 1989: Contrarreforma y Barroco. Lecturas iconográficas y iconológicas. Madrid: Alianza.

Primož TRUBAR, 2002: Zbrana dela. I-IV. Ljubljana: Rokus.

\section{SUMMARY}

This article provides a comparison between Primož Trubar (1508-1586) and Bartolomé de Las Casas (1484-1566). Trubar and Las Casas were contemporaries who actively shaped the time they lived in. The role of Primož Trubar in Slovene literature cannot be compared to the place that Spanish and Hispanic literary history has assigned to Bartolomé de Las Casas. In spite of this, it is possible to draw several parallels regarding the life and work of both authors: they both travelled extensively, they caused conflicts due to their activities and as a consequence they often had to defend themselves; their opus is extensive, their genre being semi-literary, and their style is quite similar (for example, in their prefaces they take into account the addressee, they talk with compassion about the people that they represent, they attack their opponents with enthusiasm - the technique of black and white painting is noticeable). Regardless of the numerous similarities, they are distinguished and firmly defined especially by the sense of belonging to the two great religious movements of the $16^{\text {th }}$ century: post Tridentine reform of the Roman Catholic Church and the appearance of the Reformed Protestant Church. Taking into account this opposition, it is also possible to reflect on a different view regarding the significance of an image with both authors, the difference being in the content as well as form. 